\title{
STUDI TENTANG RENDAHNYA KEMAMPUAN MEMBACA PESERTA DIDIK KELAS II SDN-8 MENTENG PALANGKA RAYA
}

\author{
(Study about Low of Students' Reading Ability on the Second Grade Students \\ of SDN-8 Menteng Palangka Raya)
}

\author{
SUNIATI \\ Program Studi Pendidikan Guru Sekolah Dasar (PGSD) Fakultas Keguruan dan IImu Pendidikan \\ Universitas Muhammadiyah Palangkaraya \\ JI. RTA Milono Km.1,5 Palangka Raya, Kalimantan Tengah 73111 \\ e-mail : Suni_ati99@yahoo.com
}

\begin{abstract}
This study aims to determine the low of students' reading ability on the second grade students of SDN-8 Menteng Palangka Raya. This research uses descriptive method. The population in this study were all students of class II Which are divided into two classes: II-A and II-B is numbered 34 people. The sample in this study is the entire study population totaling 34 students. The results of the study are the dominant factor until very low dominant of reading ability of the second grade students of SDN-8 Menteng Palangka Raya, that students in reading did not pay attention to punctuation there are 34 students or $100 \%$. Students do not understand the sentence he read there 32 students or $94.11 \%$. Students do not know how to read, there are 22 people or $64.70 \%$ of students. Students in reading omit letters or words there are 22 people or $64.70 \%$ of students, and students error pronounce the letter that sounds similar to the letters $b$ and $p$ there are 21 students or $61.77 \%$.
\end{abstract}

Keywords: low of reading ability

\begin{abstract}
ABSTRAK
Penelitian ini bertujuan untuk mengetahui rendahnya kemampuan membaca peserta didik Kelas II SDN-8 Menteng Palangka Raya. Penelitian ini menggunakan metode deskriptif. Populasi dalam penelitian ini adalah seluruh peserta didik kelas II Yang terbagi menjadi dua kelas yaitu II-A dan II-B yaitu berjumlah 34 orang. Sampel dalam penelitian ini adalah seluruh jumlah populasi penelitian yang berjumlah 34 orang peserta didik. Hasil penelitian faktor yang dominan sampai yang sangat dominan rendahnya kemampuan membaca peserta didik Kelas II SDN-8 Menteng Palangka Raya, bahwa peserta didik pada saat membaca tidak memperhatikan tanda baca ada 34 orang peserta didik atau $100 \%$. Peserta didik tidak memahami kalimat yang dibacanya ada 32 orang peserta didik atau $94,11 \%$. Peserta didik tidak lancar membaca ada 22 orang peserta didik atau 64,70\%. Peserta didik pada saat membaca menghilangkan huruf atau kata ada 22 orang peserta didik atau 64,70\%, dan peserta didik kesalahan melafalkan huruf yang bunyinya mirip seperti huruf $b$ dengan $p$ ada 21 orang peserta didik atau $61,77 \%$.
\end{abstract}

Kata kunci : rendahnya kemampuan membaca

\section{PENDAHULUAN}

Membaca di sekolah dasar merupakan landasan bagi tingkat pendidikan yang lebih tinggi. Sebagai kemampuan yang mendasari tingkat pendidikan selanjutnya, membaca perlu mendapat perhatian pendidik, sebab jika dasarnya tidak kuat pada tahapan pendidikan berikutnya peserta didik akan mengalami kesulitan untuk dapat memperoleh dan memiliki pengetahuan. Kemampuan membaca tidak dapat dilakukan tanpa sarana-sarana yang perlu terutama bahan-bahan bacaan yang baik, minat baca pada anak, dorongan orang tua, (masyarakat). Maka kemampuan membaca merupakan fasilitas yang dapat menjunjung tinggi harkat dan martabat bangsa, tetapi yang menjadi 
kendala pada kenyataannya sekarang masih rendahnya kemampuan membaca peserta didik dan perlu untuk ditingkatkan terutama dorongan dari orang tua (masyarakat).

Salah satu aspek yang memegang peranan penting dalam mata pelajaran Bahasa Indonesia yakni pembelajaran membaca. Tanpa memiliki kemampuan membaca yang memadai sejak dini, peserta didik akan mengalami kesulitan belajar dikemudian hari. Sebab dengan membaca peserta didik akan dapat memperoleh pengetahuan yang sangat bermanfaat bagi pertumbuhan dan perkembangan daya nalar, sosial dan emosionalnya.

Membaca secara formal diajarkan di sekolah pada tahun-tahun awal seperti kelas 1 dan 2 SD (Rahim, 2005) sehingga langkah terpenting untuk mengatasi permasalahan kemampuan membaca yang rendah adalah menemukan metode pengajaran yang tepat dan efisien. Perkembangan dunia pendidikan saat ini cukup menggembirakan ditandai dengan munculnya metode-metode pengajaran baru yang lebih inovatif. Metode pengajaran ini lebih interaktif dan juga tidak hanya menggunakan setting di kelas saja. Bahkan metode baru ini sudah disinergikan dengan perkembangan teknologi. Metode-metode baru tersebut secara efektif dapat meningkatkan kemampuan peserta didik.

Pengajaran membaca harus memperhatikan kebiasaan cara berpikir teratur dan baik. Hal ini disebabkan membaca sebagai proses yang sangat kompleks, dengan melibatkan semua proses mental yang tinggi, seperti ingatan, pemikiran daya khayal, pengaturan, penerapan dan pemecahan masalah. Mackey
(Iskandarwassid: 246) melihat hubungan antara membaca dengan pengajaran bahasa sebagai "although this involves neither listening to the language nor speaking it, reading is an important means of maintaining of contact with a second language".

Berdasarkan Silabus Bahasa Indonesia Kelas II Semester I, Peraturan Menteri Pendidikakan Nasional Nomor 22 Tahun 2006 tentang Standar Kompetensi yang harus dikuasai peserta didik kelas II semester I pada aspek membaca peserta didik diharapkan dapat memahami teks pendek dengan membaca lancar dan membaca puisi anak, dengan begitu proses pembelajaran tersebut ditemukan partisipasi peserta didik. Pada umumnya peserta didik hanya mengharapkan belajar di sekolah tanpa belajar kembali di rumah pelajaran yang telah diajarkan guru di sekolah sehingga kemampuan membaca peserta didik masih rendah.

Membaca permulaan dalam pengertian teori keterampilan membaca permulaan yang dimaksud oleh Abidin (2010:114) yaitu membaca yang menekankan pada proses. Membaca permulaan yang menjadi acuan adalah membaca merupakan proses recording dan decoding.

Membaca permulaan merupakan tahapan proses belajar membaca bagi peserta didik sekolah dasar kelas awal. Peserta didik belajar untuk memperoleh kemampuan dan menguasai teknik-teknik membaca dan menangkap isi bacaan dengan baik. Oleh karena itu pendidik perlu merancang pembelajaran membaca dengan baik sehingga mampu menumbuhkan kebiasan membaca sebagai suatu yang menyenangkan. 
Pembelajaran membaca permulaan diberikan pada Kelas I dan Kelas II. Tujuannya adalah supaya peserta didik memiliki kemampuan memahami dan menyuarakan tulisan dengan intonasi yang benar, sebagai dasar untuk dapat membaca lanjut. Tujuan membaca permulaan tidak terlepas dari tujuan pendidikan pada umumnya dan tujuan pengajaran pada khususnya. Tujuan pengajaran membaca permulaan pada dasarnya adalah memberikan bekal pengetahuan dan kemampuan peserta didik untuk menguasai teknik-teknik membaca dan menangkap isi bacaan dengan baik dan benar.

Setelah melakukan observasi di SDN-8 Menteng Palangka Raya pada Kelas II mata pelajaran Bahasa Indonesia, dapat diketahui bahwa kemampuan membaca permulaan peserta didik masih rendah. Berdasarkan data yang diperoleh dari Wali Kelas II SDN-8 Menteng Palangkaraya, menunjukkan bahwa keseluruhan peserta didik Kelas II-A dan II-B berjumlah 34 peserta didik, kriteria ketuntasan minimum (KKM) di SDN-8 Menteng Palangka Raya mata pelajaran Bahasa Indonesia 60. Terdapat 13 peserta didik mendapat nilai membaca rata-rata 7,0 dan 21 peserta didik mendapat nilai membaca rata-rata 5,0 atau di bawah kriteria ketuntasan minimum (KKM). Sehubungan dengan uraian tersebut, peneliti tertarik untuk mengangkat judul "Studi Tentang Rendahnya Kemampuan Membaca Peserta Didik Kelas II SDN-8 Menteng Palangka Raya.

\section{METODOLOGI}

Penelitian ini dilaksanakan di SDN-8 Menteng Palangka Raya yang berlokasi di Jalan Damang Pijar I No. 53 Palangka Raya khususnya pada peserta didik Kelas II pada bulan Oktober sampai November 2016.

Penelitian ini menggunakan metode deskriptif, yang dimaksudkan untuk mengumpulkan informasi mengenai status suatu gejala yang ada, yaitu keadaan gejala menurut apa adanya pada saat penelitian dilakukan. Menurut Moh. Nazir (2005:54) bahwa metode deskriptif adalah suatu metode dalam meneliti status sekelompok manusia, suatu objek, suatu set kondisi, suatu sistem pemikiran ataupun suatu kelas peristiwa pada masa sekarang. Tujuan dari penelitian deskriptif ini adalah untuk membuat deskriptif, gambaran atau lukisan secara sistematis, faktual dan akurat mengenai faktafakta, sifat-sifat serta hubungan antara fenomena yang diselidiki.

Populasi yang diambil dalam penelitian ini adalah peserta didik Kelas II SDN-8 Menteng Palangka Raya Tahun Pejaran 2016/2017 yang terdiri dari dua kelas yaitu Kelas II-A dan II-B. Sedangkan sampel adalah sebagian dari populasi. Menurut Sugiyono (2006:56), menjelaskan bahwa "sampel adalah sebagian dari jumlah dan karakteristik yang dimiliki populasi tersebut". Berdasarkan pendapat tersebut, maka peneliti menyimpulkan bahwa sampel penelitian ini adalah seluruh jumlah dari populasi. Hal tersebut sesuai dengan pendapat Suharsimi Arikunto (2003:135), "Apabila subjeknya kurang dari 100, lebih baik diambil semua sehingga penelitiannya merupakan penelitian populasi". Sampel dalam penelitian ini berjumlah 34 orang peserta didik yang terdiri dari 18 orang peserta didik di kelas II-A dan 16 orang peserta didik di kelas II-B. 
Definisi operasional variabel pada penelitian ini yaitu faktor penyebab yang dominan rendahnya kemampuan membaca peserta didik adalah faktor yang disebabkan dari dalam diri peserta didik terutama minat baca yang kurang dibiasakan untuk belajar membaca. Hal ini menyebabkan peserta didik kesulitan dalam belajar membaca. Hal tersebut sejalan dengan pendapat Muhibbin Syah (2002:166) yang menyatakan bahwa "faktor rendahnya kemampuan membaca peserta didik yaitu kurangnya minat baca dan kurangnya kebiasaan belajar membaca hal ini menyebabkan kemampuan membaca peserta didik tidak terasah".

Sedangkan indikator-indikator faktor penyebab yang dominan rendahnya kemampuan membaca permulaan peserta didik, yaitu:

a. Peserta didik kurang mengenal huruf.

b. Peserta didik tidak memahami kalimat yang dibacanya.

c. Peserta didik tidak lancar membaca

d. Peserta didik kesalahan melafalkan huruf yang bunyinya mirip, seperti: bunyihuruf $b$ dengan $p$.

e. Peserta didik tidak menguasai tanda baca.

Teknik pengumpulan data yang digunakan dalam penelitian ini adalah dengan menggunakan observasi. Sedangkan instrumen yang digunakan untuk pengumpulan data adalah instrumen hasil belajar untuk mengambil data kemampuan membaca peserta didik.

Sebagaimana telah dikemukakan sebelumnya dalam variabel penelitian dan tujuan penelitian yang sudah dirumuskan oleh peneliti bahwa penelitian ini hanya terdiri dari satu variabel saja dan mencari faktor yang dominan rendahnya kemampuan membaca permulaan peserta didik kelas II SDN-8 Menteng Palangkaraya. Jadi menurut peneliti, penelitian ini sangat relevan menggunakan teknik analisis data persentase. Data dan informasi yang diperoleh dari observasi dianalisis dengan menggunakan rumus persentase yang diambil dari Anas Sudijono (2010:43) sebagai berikut:

$$
\mathrm{P}=\frac{F}{N} \times 100 \%
$$

Keterangan :

$\begin{array}{rlll}\mathrm{P}: \text { : } & \text { Angka persentase/persentase jawaban } \\ \mathrm{F} \quad: & \text { Frekuensi yang sedang dicari } \\ & \text { persentasenya/frekuensi jawaban } \\ & \text { responden } \\ \mathrm{N} \quad: & \text { Jumlah frekuensi/jumlah seluruh } \\ & \text { populasi } \\ 100 \%: \quad & \text { Pengali tetap }\end{array}$ Untuk mempermudah menilai hasil pengolahan data dalam penelitian ini digunakanlah kriteria penelitian yang diambil dari Suharsimi Arikunto dalam Dwi Wahyuni Nunie Setiawati (2011:26) sebagai berikut:

$$
\begin{array}{ll}
0 \%-40 \% & : \text { Tidak Dominan } \\
41 \%-60 \% & : \text { Cukup Dominan } \\
61 \%-80 \% & : \text { Dominan } \\
81 \%-100 \% & : \text { Sangat Dominan }
\end{array}
$$

\section{HASIL DAN PEMBAHASAN}

Hasil analisis Studi Tentang Rendahnya Kemampuan Membaca Peserta Didik Kelas II SDN-8 Menteng Palangka Raya yang diperoleh melalui hasil pengumpulan data dengan observasi terhadap 34 orang peserta didik. hasil observasi peserta didik disajikan pada Tabel 1 . 
Tabel 1. Hasil observasi faktor dominan rendahnya kemampuan membaca peserta didik Kelas II SDN-8 Menteng Palangka Raya

\begin{tabular}{|c|c|c|c|c|c|c|}
\hline No. & Indikator & Aspek Yang Dinilai & $\begin{array}{c}\text { Frekuensi } \\
\mathrm{Ya}\end{array}$ & $\begin{array}{l}\% \\
\text { Ya }\end{array}$ & $\begin{array}{l}\text { Frekuensi } \\
\text { Tidak }\end{array}$ & $\begin{array}{c}\% \\
\text { Tidak }\end{array}$ \\
\hline 1. & $\begin{array}{l}\text { Peserta didik kurang } \\
\text { mengenal huruf, bunyi, } \\
\text { bahasa, dan bentuk } \\
\text { kalimat }\end{array}$ & $\begin{array}{l}\text { - Peserta didik kurang } \\
\text { mengenal huruf }\end{array}$ & 14 & $41,17 \%$ & 20 & $58,82 \%$ \\
\hline 2. & $\begin{array}{l}\text { Peserta didik tidak } \\
\text { memahami kalimat } \\
\text { yang dibacanya }\end{array}$ & $\begin{array}{l}\text { - Peserta didik tidak } \\
\text { memahami kalimat } \\
\text { yang dibacanya }\end{array}$ & 92 & $94,11 \%$ & 2 & $5,88 \%$ \\
\hline \multirow[t]{2}{*}{3.} & \multirow[t]{2}{*}{$\begin{array}{l}\text { Peserta didik tidak } \\
\text { lancar membaca }\end{array}$} & $\begin{array}{l}\text { - Peserta didik tidak } \\
\text { lancar membaca }\end{array}$ & 22 & $64,70 \%$ & 12 & $35,30 \%$ \\
\hline & & $\begin{array}{l}\text { - Peserta didik } \\
\text { kesulitan merangkai } \\
\text { huruf. }\end{array}$ & 20 & $58,8 \%$ & 14 & $41,17 \%$ \\
\hline \multirow[t]{2}{*}{4.} & \multirow[t]{2}{*}{$\begin{array}{l}\text { Peserta didik } \\
\text { kesalahan melafalkan } \\
\text { huruf yang bunyinya } \\
\text { mirip seperti huruf b } \\
\text { dengan } \mathrm{p} \text {. }\end{array}$} & $\begin{array}{l}\text { - Peserta didik } \\
\text { kesalahan } \\
\text { melafalkan huruf } \\
\text { yang bunyinya mirip } \\
\text { seperti hurup b }\end{array}$ & 21 & $61,77 \%$ & 13 & $38,23 \%$ \\
\hline & & $\begin{array}{l}\text { dengan p. } \\
\text { - Peserta didik pada } \\
\text { saat membaca } \\
\text { menghilangkan huruf } \\
\text { atau kata }\end{array}$ & 22 & $64,70 \%$ & 12 & $35,30 \%$ \\
\hline 5. & $\begin{array}{l}\text { Peserta didik tidak } \\
\text { menguasai tanda baca }\end{array}$ & $\begin{array}{l}\text { - Peserta didik pada } \\
\text { saat membaca tidak } \\
\text { memperhatikan } \\
\text { tanda baca. }\end{array}$ & 100 & $100 \%$ & 0 & $0 \%$ \\
\hline
\end{tabular}

Berdasarkan Tabel 1, faktor penyebab rendahnya kemampuan membaca peserta didik Kelas II SDN-8 Menteng Palangka Raya dapat dikategorikan sebagai berikut :

a. Berdasarkan 34 peserta didik, diketahui sebanyak 14 peserta didik $(41,17 \%)$ menjawab "Ya" bahwa mereka kurang mengenal huruf dan sebanyak 20 peserta didik $(58,82 \%)$ yang menjawab "Tidak". Hal tersebut berarti $41,17 \%$ peserta didik menyatakan mereka kurang mengenal huruf, data tersebut termasuk kategori cukup dominan. b. Berdasarkan 34 peserta didik, diketahui sebanyak 32 peserta didik (94,11\%) menjawab "Ya" bahwa mereka tidak memahami kalimat yang dibacanya dan sebanyak 2 peserta didik (5,88\%) yang menjawab "Tidak". Hal tersebut berarti 94,11\% peserta didik menyatakan mereka tidak memahami kalimat yang dibacanya, data tersebut termasuk kategori sangat dominan.

c. Berdasarkan 34 peserta didik, diketahui sebanyak 22 peserta didik (64,70\%) menjawab "Ya" bahwa mereka tidak lancar membaca dan sebanyak 12 peserta didik 
$(35,30 \%)$ yang menjawab "Tidak". Hal tersebut berarti $64,70 \%$ peserta didik menyatakan mereka tidak lancar membaca, data tersebut termasuk kategori dominan.

d. Berdasarkan 34 peserta didik, diketahui sebanyak 20 peserta didik $(58,82 \%)$ menjawab "Ya" bahwa mereka kesulitan merangkai huruf dan sebanyak 14 peserta didik $(41,17 \%)$ yang menjawab "Tidak". Hal tersebut berarti 58,82\% peserta didik menyatakan mereka kesulitan merangkai huruf, data tersebut termasuk kategori cukup dominan.

e. Berdasarkan 34 peserta didik, diketahui sebanyak 21 peserta didik $(61,77 \%)$ menjawab "Ya" bahwa mereka bingung membaca huruf yang bunyinya mirip seperti huruf $b$ dengan $p$ dan sebanyak 13 peserta didik (38,23\%) yang menjawab "Tidak". Hal tersebut berarti 61,77\% peserta didik menyatakan mereka bingung membaca huruf yang bunyinya mirip seperti huruf $b$ dengan $p$, data tersebut termasuk kategori dominan.

f. Berdasarkan 34 peserta didik, diketahui sebanyak 22 peserta didik (64,70\%) menjawab "Ya" bahwa mereka pada saat membaca menghilangkan huruf atau kata dan sebanyak 12 peserta didik $(35,30 \%)$ yang menjawab "Tidak". Hal tersebut berarti $64,70 \%$ peserta didik menyatakan mereka pada saat membaca menghilangkan huruf atau kata, data tersebut termasuk kategori dominan.

g. Berdasarkan 34 peserta didik, diketahui sebanyak 34 peserta didik (100\%) menjawab "Ya" bahwa mereka pada saat membaca tidak memperhatikan tanda baca dan sebanyak 0 peserta didik (0\%) yang menjawab "Tidak". Hal tersebut berarti $100 \%$ peserta didik menyatakan mereka pada saat membaca tidak memperhatikan tanda baca, data tersebut termasuk kategori sangat dominan.

\section{KESIMPULAN DAN SARAN}

\section{Kesimpulan}

Berdasarkan hasil penelitian dan analisis data dapat ditarik kesimpulan bahwa dominan sampai yang sangat dominan kemampuan membaca peserta didik Kelas II SDN-8 Menteng Palangka Raya dalam pembelajaran Bahasa Indonesia yaitu :

a. Peserta didik pada saat membaca tidak memperhatikan tanda baca $100 \%$ termasuk kategori sangat dominan.

b. Peserta didik tidak memahami kalimat yang dibacanya $94,11 \%$ termasuk kategori sangat dominan.

c. Peserta didik kurang lancar membaca $64,70 \%$ termasuk kategori dominan.

d. Peserta didik pada saat membaca menghilangkan huruf atau kata 64,70\% termasuk kategori dominan.

e. Peserta didik bingung melafalkan huruf yang bunyinya mirip, seperti: bunyi huruf $b$ dengan $p$ $61,77 \%$ termasuk kategori dominan.

\section{Saran}

a. Bagi kepala sekolah disarankan mampu membuat kebijakan yang berdampak positif dengan mengajak guru-guru berdiskusi menyusun strategi pembelajaran sehingga kemampuan membaca peserta didik dapat ditingkatkan menjadi lebih baik lagi.

b. Bagi guru disarankan dapat menyusun strategi pembelajaran misalnya belajar sambil bermain 
untuk dapat meningkatkan kemampuan membaca peserta didik.

c. Bagi peneliti lain, penelitian ini dapat dijadikan sebagai bahan acuan untuk penelitian lebih lanjut lagi mengenai faktor yang dominan rendahnya kemampuan membaca peserta didik Kelas II SDN-8 Menteng Palangka Raya.

\section{DAFTAR PUSTAKA}

Abidin, (2010), Pembelajaran Membaca di SD, Jakarta : Depertemen Pendidikan Nasional

Aderson, (20/05/2016), Pengertian Membaca Permulaan.http//ipotes.wordpress. com.

Adi Suryanto, (2008), Evaluasi Pembelajaran Di SD, Jakarta: Depertemen Pendidikan Nasional.

Ali Hidayat, (2007). Metode Penelitian, Jakarta : Rineka Cipta

Depdiknas, (2006), Peraturan Mentri Pendidikan Nasional Nomor 22 Tahun 2006 Tentang Standar Kompetensi kelas II Semester I, Jakarta : Tim Penulis

Depdiknas (2000), Metodik Khusus Pengajaran Bahasa Indonesia di Sekolah Dasar. Jakarta: Depdiknas Dirjen Dikdasmen.

Hendrariahdo, (16/06/2016), Keadaan lingkungan keluarga. $\quad \mathrm{http} / / / \mathrm{www} . \mathrm{sabd}$ aspace.org/masalah kemampuan membaca berbahasa Indonesia.

Moh. Nazir, (2005), Metode Penelitian, Bogor Selatan: Ghalia Indonesia Muhammad Amin, (16/06/2016). Metode Suku Kata http://typecet.com/pdt/pengertian membaca permulaan-bagi anak kelas rendah SD Intml.

Momo, (2002), Pengajaran Membaca Disekolah Dasar, Jakarta: Bumi Angkasa.

Muhibbin Syah, (2002), Faktor-faktor Yang Mempengaruhi Kemampuan Membaca, Jakarta: Bumi Angkasa.
M. Toha Anggoro, (2003), Metode Penelitian, Jakarta: Universitas Terbuka.

Purwanto, (2000), Metodologi Pengajaran Bahasa Indonesia di Sekolah Dasar. Jakarta: PT Rosda Jayaputra.

Rita Wati, (2003), Struktur Pengajaran Tata Bahasa Indonesia Untuk SMTA. Surabaya. Indah.

Sri Nuryati, (2002), Dasar-dasar Membaca, Jakarta : Bumi Angkasa

Sugiyono, (2006), Statistik Untuk Penelitian. Jakarta: Depdikbud.

Suharsimi Arikunto, (2003), Manajemen Penelitian, Jakarta: Rineka Cipta.

Sumadi Suryabrata, (2006), Metodologi Penelitian. Jakarta: Gramedia.

Sutrisno Hadi, (2000), Metodologi Penelitian, Jakarta : Rineka Cipta.

Tim Penyusun, (2008), Buku Pedoman Penulisan, Skripsi, Palangkaraya; Universitas Muhammadiyah Palangkaraya.

Walgito, (2000), Metode Penelitian, Jakarta : Rineka Cipta. 